\title{
Start-up Nation? Slave Wealth and Entrepreneurship in Civil War Maryland
}

\author{
Felipe GonzÁlez, Guillermo Marshall, \\ AND SuRESH NAIDU
}

\begin{abstract}
Slave property rights yielded a source of collateral as well as a coerced labor force. Using data from Dun and Bradstreet linked to the 1860 census and slave schedules in Maryland, we find that slaveowners were more likely to start businesses prior to the uncompensated 1864 emancipation, even conditional on total wealth and human capital, and this advantage disappears after emancipation. We assess a number of potential explanations, and find suggestive evidence that this is due to the superiority of slave wealth as a source of collateral for credit rather than any advantage in production. The collateral dimension of slave property magnifies its importance to historical American economic development.
\end{abstract}

Slave property rights were a key institution in American economic

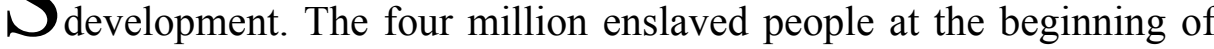
the Civil War were an unwilling workforce that made Southern agriculture the immensely lucrative and dynamic system that the Confederacy sacrificed much to defend. Whether by gang labor and pace of work or frictionless movement to new territories on the frontier, the advantages of slavery in Southern agriculture are well-documented (Fogel and Engerman 1974; Wright 2006).

However, even as the bulk of the economics literature on slavery has focused on slaves as an agricultural labor force, many of the other contributions of slave property to American economic development have been neglected. This is despite the injunctions of prominent economic

The Journal of Economic History, Vol. 77, No. 2 (June 2017). (C) The Economic History Association. All rights reserved. doi: 10.1017/S0022050717000493

Felipe González is Ph.D. Candidate, University of California, Berkeley, Department of Economics, 530 Evans Hall \#3880, Berkeley, CA 94720-3880. E-mail: fgonzalez@econ.berkeley. edu. Guillermo Marshall is Assistant Professor, University of Illinois at Urbana-Champaign, Department of Economics, 214 David Kinley Hall, 1407 W Gregory St, Urbana, IL 61801. E-mail: gmarshll@illinois.edu. Suresh Naidu is Associate Professor, Columbia University, Department of Economics and SIPA, 1405 IAB MC 3328, 420 W. 118th St., New York, NY 10027. E-mail: sn2430@columbia.edu.

We would like to thank seminar participants at the NBER, PUC-Chile, Stanford, and UC Berkeley for many helpful comments. Special thanks to Joseph Ferrie for support in the early stages of the project. John Clegg, Ellora Derenoncourt, Christopher Muller, and Stanley Engerman all provided valuable feedback. Jacob Moscona-Skolnik provided outstanding research assistance. 
historians. Gavin Wright (2006, p. 69) notes that "An important component of planter mobility was the capacity to establish and maintain credit relationships across long distances, arrangements ultimately based on the asset value and liquid character of slave property." Slaves were financial assets, readily sold on ubiquitous auction markets (Tadman 1990), pledged as collateral for loans (Martin 2010), and used to settle payments and debts over long distances (Kilbourne 1995). Slaves, as chattel property and not real estate, were exempt from entail laws that shielded assets from creditors in the event of a default (Priest 2015). Given the presence of relatively more liquid markets in slave assets, slave wealth could have allowed access to finance on better terms than real estate or other major types of wealth present in the antebellum Southern economy, facilitating business startup. This article examines this role of slave wealth in business formation in Maryland during the Civil War, using the 1864 uncompensated abolition as a shock to slaveowner wealth.

We find that 1860 slave wealth, conditional on total wealth, was significantly correlated with business formation in Maryland between 1860 and 1863, and this relationship disappeared following the 1864 constitutional abolition. While there are a number of explanations for this, we use historical evidence together with economic theory to assess various competing accounts. We find evidence that this was due to the high quality of slave wealth as collateral, rather than any advantage in production, and this is confirmed in specifications that focus on the fraction of wealth held in enslaved people. We discuss a simple model showing that the collateral channel affected business formation, while the cost of production channel affected both business formation and business destruction. Consistent with this, we find that there was no effect of abolition on differential destruction of businesses owned by slaveowners. We present qualitative evidence that the slave rental market was active through 1864, and that wages did not abruptly change with abolition, further suggesting that there was little productive advantage conferred by slave ownership in Maryland. We see that slaveowners had an advantage in starting businesses even in non-agricultural, urban sectors, which were much less slave-intensive in production, and take this as further evidence of the financial channel. Indeed, we see the largest effects in the merchant sector, which was particularly credit dependent and where enslaved people were unlikely to confer much productive advantage. In sum, our article provides evidence of a credit market advantage for American slave property holders. 


\section{Slave Wealth/Entrepreneurship in Civil War Maryland 375}

The importance of wealth and liquidity for entrepreneurship is well documented in both developed and developing economies. ${ }^{1}$ However, little of this literature has considered differences in the composition of wealth, although Charles W. Calomiris et al. (2015) and Murillo Campello and Mauricio Larrain (2015) are recent exceptions. A common source of identification is exogenous housing price shocks (Hurst and Lusardi 2004; Fairlie and Krashinsky 2012), as well as inheritances or cash windfalls. These types of wealth differ in their liquidity, which may affect their ability to be pledged as collateral to obtain start-up funding. We take advantage of one of the largest destructions of wealth in U.S. history, abolition of slavery, to obtain estimates not only of the effect of wealth, but also its composition, on business formation.

A recent qualitative literature investigates the role of slaves in financial contracts. Richard Kilbourne's "Debt, Investment, Slaves" is perhaps the most detailed monograph on credit networks in the slave economy. $\mathrm{He}$ shows that slaves were extensively deployed in credit market relationships. By inspecting credit relations in East Feliciana Parish in the nineteenth century, Kilbourne finds that slaves were sold for cash, while land was sold on credit, and this fact made slaves much more liquid and thus preferred as collateral. Kilbourne concludes that "The liquidity evident in the slave market at all times dwarfed that of the land market...the slave market accounted for almost 80 percent of the total cash market for both land and slaves" (1995, p. 50).

Historians have suggested that these credit relationships were important to the functioning of the larger Southern, and even the Atlantic economy. Walter Johnson (2013) discusses the chains of credit that linked Mississippi planters to cotton factors in New Orleans, who in turn relied on credit from New York bankers and Liverpool merchants. ${ }^{2}$ Bonnie Martin (2010) shows, using a sample of mortgages, that the money raised by slaves mortgaged in Louisiana, South Carolina, and Virginia was often larger than the amount raised on the non-slave mortgages. Martin reports that 88,82 , and 33 percent of funds raised via mortgages in Louisiana, South Carolina, and Virginia, respectively, in the national era were raised

\footnotetext{
${ }^{1}$ See also Evans and Jovanovic (1989), Evans and Leighton (1989), Meyer (1990), HoltzEakin, Joulfaian, and Rosen (1994), Lindh and Ohlsson (1996), Blanchflower and Oswald (1998), Fairlie (1999), Holtz-Eakin and Rosen (2004), Lindh and Ohlsson (1998), Dunn and Holtz-Eakin (2000), Johansson (2000), Taylor (2001), Zissimopolous and Karoly (2007), and Nykvist (2008).

${ }^{2}$ For example, the 1837 Financial register wrote "Everyone knows that the cotton planters of the Southwestern states procure large supplies of clothing for their slaves, of every article required for their own consumption, upon credit from neighboring merchants in anticipation of next year's crop." See Johnson (2013, p. 261).
} 
with slave mortgages. But quantitative estimates of the effect of slave wealth on business formation have been absent.

The liquidity of the slave market throughout the South is also well documented. Michael Tadman (1990) shows that the speculative market for slaves was extremely active, with planters regularly selling their slaves to traders at local auctions. Slave traders, acting as speculators and arbitraging price differences, helped maintain liquidity in the slave markets. A large literature has explored to what extent the interstate transport of slaves was conducted by traders (rather than slaveowner migration). The recent literature concludes that this number is high, with Tadman (1990), Jonathan B. Pritchett (2001), Steven Deyle (2005), and Richard Steckel and Nicolas L. Ziebarth (2013) all documenting that between 50 and 70 percent of interstate slave movements was due to traders. The liquidity of the market is also supported by other financial instruments that underwrote slave property rights, such as insurance contracts and warranties. Insurance contracts allowed slaveowners to hedge against slave illnesses and death (Murphy 2005), and tended to be used more by industrial and urban slaveowners (Levy 2012). Warranties for slave defects (Wahl 1996) mitigated, although likely did not eliminate, adverse selection problems in the slave market (Greenwald and Glasspiegel 1982). One curious case in Lynchburg, VA involves a slave, Burwell, given the power of attorney to mortgage himself for $\$ 1,400$, keep $\$ 50$ and forward the rest of the money to his master.

This modern understanding of slavery as a sophisticated system of property rights and financial contracts contrasts with an older literature that held that slaveowners were less likely to pursue modern business activities. But the implication that slaves could be a source of collateral would not be surprising to economists. A well-known argument by Hernando De Soto (2003), held that formal property rights in land were important for transforming informal assets into sources of collateral. Timothy Besley and Maitreesh Ghatak (2010) provide a comprehensive model and a survey of the literature on property rights and development, and this particular effect of secure property rights has received mixed empirical confirmation. Sebastian Galiani and Ernesto Schargrodsky (2010) find no effects of squatter titling on credit access in Argentina, and Erica Field and Maximo Torero (2008) find that property rights in Peru led to increased public sector credit, but no increase in private sector credit. Slavery, by giving formal title to other people's labor, allowed human bodies to be pledged as collateral, which should allow slaveowners access to capital for many different kinds of activities, not just those involving slave labor. 


\section{Slavery, Credit, and Abolition in Maryland}

By 1860, Maryland was the archetypical "middle ground" (Fields 1984). The northern part of the state was urban, industrialized, and overwhelmingly free. Baltimore had just over 2,000 slaveowners and almost 5,500 slaves in 1860 , with slaveowners roughly 1 percent of its population. Southern Maryland and the Chesapeake area, however, were still very much slave country, and slaveowners exerted influence well beyond their share of the state's economic activity (Fields 1984). Politically and socially, Maryland's holders of human property exercised substantial sway over politics, passing an 1851 constitution that took the right of abolition out of legislative jurisdiction. Rural Maryland elites took full advantage of the inclusion of slaves in the legislature seat allocation ${ }^{3}$ and the territorial allocation of the state senate to dominate Baltimore and the North politically. One symptom of this was that slave values were capped at $\$ 400$ for the purpose of tax assessment, giving a tax advantage to slave assets relative to land and other forms of property. As we will see, the political defense of slave property was not purely ideological. Despite their relatively small holdings and low agricultural profits, Maryland slaveowners benefited from their property via the extensive slave markets and contracts available. ${ }^{4}$

The total value of Maryland slaves at the time of emancipation was roughly 30 million dollars, a relatively small fraction (just over 7 percent) of total state wealth in 1860 . However, the sale market for slaves was quite active. William Calderhead (1972) documents roughly one sale for every 10 slaves between 1830 and 1840 in slaveholding Maryland counties. Max L. Grivno (2007) writes of the national demand for slaves substituting for weak local demand: "By the 1850s, slave prices in northern Maryland were largely underwritten by the interstate trade." "A prime able-bodied slave is worth three times as much to the cotton or sugar planter as to the Maryland agriculturalist," observed the Frederick Examiner newspaper in November 1858. And it was observed that "The principal interest of the Maryland slaveowner is ... production for the southern market; for if that demand were cut off, the value of this property would depreciate from sixty to seventy percent" (Grivno 2007, p. 95).

\footnotetext{
${ }^{3}$ Maryland apportioned seats in the state legislature counting slaves as full citizens, not threefifths, for the purpose of representation.

${ }^{4}$ Besides lifetime slaves, Maryland also had free blacks on indentured labor contracts (Morris 1948) and "term slaves" who were owned and traded until a fixed age or date.
} 
Importantly for our analysis, slave ownership was not a prerequisite for using slave labor. As Barbara Fields writes "The small size of holdings in Maryland combined with the variability of labor requirements, especially on the part of urban employers and farmers engaged in mixed or cereal agriculture, to make slave hiring a ubiquitous phenomenon, much more common than sale" (1984, p. 27). The active slave rental market, together with its relatively sophisticated economy, make Maryland an ideal location to study the financial dimension of slavery. Slave ownership did not necessarily force one to engage in slave-intensive activities. Instead, one could pledge a slave as collateral for a loan, use the loan to start a business that did not use slave labor, and then rent out the slave for additional income. But slave ownership in the presence of thick rental and resale markets could facilitate a wide variety of business activities potentially far removed from slave labor. Even in the relatively advanced urban economy of Baltimore, slaveowners, while relatively few in number, had an advantage in starting businesses in the pre-1864 period.

The abolition of slavery in Maryland was idiosyncratic as well. The state as a whole was quite anti-abolition, voting less than 5 percent for Lincoln and refusing even compensated emancipation in 1862. However, as a result of this neutrality, Maryland was exempted from the Emancipation proclamation of 1863 . Instead, there was a referendum on a new constitution in late 1864 to determine whether slavery would continue in the state. This referendum was quite close, with the constitution passing by less than 1 percent of the vote. In addition, a few months before the referendum, the war department allowed all slaves to enlist, emancipating those that did. This, as much as the new constitution, destroyed slavery in Maryland. In the Online Appendix, we show evidence that Maryland was relatively optimistic about the value of slave wealth from slave purchase prices paid by Maryland participants in the New Orleans slave market.

\section{BACKGROUND AND DATA}

\section{Credit Market and Reports}

Our main data source are credit reports from the R.G. Dun \& Company Collection (R.D. Collection, Harvard Business vols. 2, 7, 8, and 9). These reports were prepared by local attorneys who were instructed to "record all facts that come to your knowledge, of persons changing their business, failing, moving away, new partnerships, etc.,... The name of every trader in your district should be reported, with all necessary particulars, 
whether they have ever purchased in this city or not"s (Lewis Tappan, circular, 20 December [1842]) (Olegario, 2006).

Using these reports, we measure business formation in Maryland. Throughout the article we refer to individuals mentioned in these reports as "entrepreneurs" or "business owners." $\mathrm{We}$ focused on entrepreneurs with a first report between January 1860 and December 1865. Following the agency's guidelines, we interpret the date of first report as the date when the agency identified a new business. The agency tracked entrepreneurs approximately twice a year, although less frequently during the Civil War, until the entrepreneurs went out of business. Similarly, we interpret the date of last report as a measure of business exit. ${ }^{7}$

There were a total of 1,580 entrepreneurs who created a business between 1860 and 1865 in Maryland. These entrepreneurs produced and sold a variety of goods, including fancy goods, groceries, and dry goods. Figure 1 presents an example of a report included in our final dataset. From the reports, we collected the (1) name of entrepreneur, (2) year and month of first record, (3) year and month of last report, (4) county, and (5) activity (e.g., fancy goods).

To expand our information about these entrepreneurs, we searched for these 1,580 individuals in the 1860 U.S. Population Census and found 620 of them. From the 1860 U.S. Population Census, we obtained each entrepreneur's year and place of birth, sex, race, literacy, county of residency, and the value of personal and real estate. We also use the IPUMS 1 percent sample of the 1860 U.S. Population Census (Ruggles et al. 2010) as a comparison group of individuals who did not appear in the credit reports. More about the data construction process, including comparisons with other data to check selection, can be found in the Online Appendix.

\footnotetext{
${ }^{5}$ As Lewis Tappan said: "a 'good collecting' attorney would be selected in each county to report on local entrepreneurs who visited New York to purchase goods. The attorney would assess each storekeeper's character, habits, business capacity, and capital, would gather other pertinent information, and would revise his report every six months. In return he would handle all subscribers' debt collections in his district" (Norris 1978). Further information about the history of R.G. Dun \& Company can be found in Norris (1978). Further information about credit reporting agencies in the nineteenth century can be found in Madison (1974) and about Lewis Tappan in Wyatt-Brown (1966).

${ }^{6}$ As stated by Madison (1974), Tappan's idea was to create "a national agency that would gather information on potential seekers of credit and disseminate the data to wholesalers and others extending credit" (our italics). Some of these entrepreneurs are merchants, and we will exploit this fact in the results section.

${ }^{7}$ Brennecke (2014) provides more information about Antebellum U.S. credit markets and the information issues associated with it. The author uses the Mercantile Agency records for New Orleans.
} 


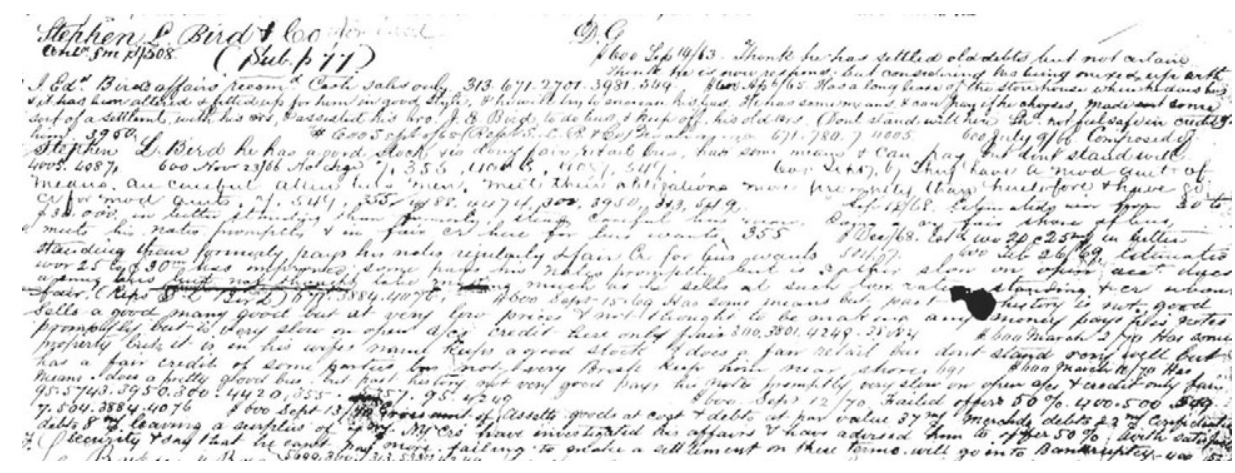

FIGURE 1

REPORTS

Notes: This is a credit report for Stephen L. Bird, classified as slaveowner in 1860, who owned a dry goods store in Baltimore. His first report is from September of 1863 and his last report is from September of 1870 .

Source: Maryland, Vols. 2, 7, 8, and 9, R.G. Dun \& Company Collection. Boston, MA: Baker Library Historical Collections, Harvard Business School, no date.

Finally, we use the 1860 U.S. Federal Census Slave Schedules to obtain information about the number of slaves owned by each individual in 1860 for both entrepreneurs and the IPUMS sample in Maryland. Using the Slaves Schedules, we are able to separate the slave wealth part of the personal estate value from the non-slave personal wealth. We calculate slave wealth by multiplying the number of slaves by $\$ 1,350$, which is the average appraised value of a 25 -year-old male slave in 1860 using data from Robert W. Fogel and Stanley L. Engerman (1976). When using average sale price instead of average appraised value, or using the New Orleans slave sale prices (even restricted to Maryland sellers and buyers) in Calomiris and Jonathan Pritchett (2016), all results remain qualitatively unchanged.

In our analysis, we restrict attention to white males between 14 and 89 years old without missing data for the covariates that we use in our empirical analysis. This gives us a sample of 526 entrepreneurs, among which 70 ( $\sim 13$ percent $)$ are classified as slaveowners.

\section{Descriptive Statistics}

In Table 1 we present descriptive statistics for the two samples of interest: (1) the Maryland IPUMS sample and (2) our sample of entrepreneurs. We present the mean and standard deviation of observable 


\section{Slave Wealth/Entrepreneurship in Civil War Maryland 381}

TABLE 1

DESCRIPTIVE STATISTICS

\begin{tabular}{|c|c|c|c|c|}
\hline & $\begin{array}{l}\text { Maryland } \\
\text { (1) }\end{array}$ & $\begin{array}{c}\text { Entrepreneurs } \\
\text { (2) }\end{array}$ & $\begin{array}{l}\text { Difference } \\
\text { (2)-(1) }\end{array}$ & $\begin{array}{l}\text { Entrepreneurs by } \\
\text { Slave-ownership }\end{array}$ \\
\hline \multicolumn{5}{|l|}{ Wealth } \\
\hline Log personal wealth & $\begin{array}{c}2.45 \\
(0.08)\end{array}$ & $\begin{array}{c}5.57 \\
(0.16)\end{array}$ & $\begin{array}{c}3.12^{* * *} \\
(0.18)\end{array}$ & $\begin{array}{l}-0.38 \\
(0.58)\end{array}$ \\
\hline Log real estate wealth & $\begin{array}{l}1.73 \\
(0.08)\end{array}$ & $\begin{array}{c}3.43 \\
(0.19)\end{array}$ & $\begin{array}{c}1.70^{* * *} \\
(0.21)\end{array}$ & $\begin{array}{c}2.31^{* * *} \\
(0.60)\end{array}$ \\
\hline Log slave wealth & $\begin{array}{c}0.34 \\
(0.04)\end{array}$ & $\begin{array}{l}1.04 \\
(0.12)\end{array}$ & $\begin{array}{c}0.69^{* * *} \\
(0.12)\end{array}$ & - \\
\hline Indicator for wealth $<200$ & $\begin{array}{c}0.56 \\
(0.01)\end{array}$ & $\begin{array}{c}0.25 \\
(0.02)\end{array}$ & $\begin{array}{c}-0.32 * * * \\
(0.02)\end{array}$ & $\begin{array}{c}0.09 \\
(0.06)\end{array}$ \\
\hline Indicator for wealth $\in[200,1700)$ & $\begin{array}{c}0.28 \\
(0.01)\end{array}$ & $\begin{array}{c}0.23 \\
(0.02)\end{array}$ & $\begin{array}{c}-0.05^{* *} \\
(0.02)\end{array}$ & $\begin{array}{c}-0.23 * * * \\
(0.03)\end{array}$ \\
\hline Indicator for wealth $\in[1700,10000)$ & $\begin{array}{c}0.10 \\
(0.01)\end{array}$ & $\begin{array}{c}0.28 \\
(0.02)\end{array}$ & $\begin{array}{c}0.18^{* * *} \\
(0.02)\end{array}$ & $\begin{array}{l}-0.03 \\
(0.06)\end{array}$ \\
\hline Indicator for wealth $\geq 10000$ & $\begin{array}{c}0.05 \\
(0.01)\end{array}$ & $\begin{array}{c}0.24 \\
(0.02)\end{array}$ & $\begin{array}{c}0.19 * * * \\
(0.02)\end{array}$ & $\begin{array}{c}0.17 * * * \\
(0.06)\end{array}$ \\
\hline Indicator for slaveowners & $\begin{array}{c}0.04 \\
(0.01)\end{array}$ & $\begin{array}{c}0.13 \\
(0.01)\end{array}$ & $\begin{array}{c}0.09 * * * \\
(0.02)\end{array}$ & - \\
\hline Fraction slave wealth & $\begin{array}{c}0.04 \\
(0.01)\end{array}$ & $\begin{array}{c}0.08 \\
(0.01)\end{array}$ & $\begin{array}{c}0.04 * * * \\
(0.01)\end{array}$ & - \\
\hline \multicolumn{5}{|l|}{ Human capital } \\
\hline Indicator for illiteracy & $\begin{array}{c}0.06 \\
(0.01)\end{array}$ & $\begin{array}{c}0.01 \\
(0.01)\end{array}$ & $\begin{array}{c}-0.05 * * * \\
(0.01)\end{array}$ & $\begin{array}{c}0.01 \\
(0.01)\end{array}$ \\
\hline Age & $\begin{array}{l}33.08 \\
(0.37)\end{array}$ & $\begin{array}{l}38.44 \\
(0.49)\end{array}$ & $\begin{array}{c}5.36 * * * \\
(0.62)\end{array}$ & $\begin{array}{c}3.3 * * * \\
(1.4)\end{array}$ \\
\hline \multicolumn{5}{|l|}{ Subsamples } \\
\hline Indicator Baltimore & $\begin{array}{c}0.44 \\
(0.01)\end{array}$ & $\begin{array}{c}0.79 \\
(0.02)\end{array}$ & $\begin{array}{c}0.35^{* * *} \\
(0.02)\end{array}$ & $\begin{array}{c}-0.22 * * * \\
(0.06)\end{array}$ \\
\hline Indicator agro-business & $\begin{array}{c}0.25 \\
(0.01)\end{array}$ & $\begin{array}{c}0.04 \\
(0.01)\end{array}$ & $\begin{array}{c}-0.21 * * * \\
(0.01)\end{array}$ & $\begin{array}{c}0.02 \\
(0.03)\end{array}$ \\
\hline Merchant & $\begin{array}{c}0.25 \\
(0.01)\end{array}$ & $\begin{array}{c}0.56 \\
(0.02)\end{array}$ & $\begin{array}{c}0.31 * * * \\
(0.03)\end{array}$ & $\begin{array}{c}0.11 \\
(0.07)\end{array}$ \\
\hline Individuals & 1,554 & 526 & 2,080 & 526 \\
\hline
\end{tabular}

Notes: Maryland representative sample from IPUMS 1 percent sample. Entrepreneurs is our construction from the R.G. Dun \& Company Collection. Slave wealth was calculated using the number of slaves and the appraised value $(\$ 1,350)$ of a 25 -year-old male slave in Maryland in 1860 (Fogel and Engerman 1976). The thresholds for the wealth indicators are the 50th, 75th, and 90 th percentiles of the empirical distribution of total wealth. Standard errors are reported in parentheses. Significance level: $* * * p<0.01, * * p<0.05, * p<0.1$.

Source: Authors' calculations. 
variables that we will use throughout the empirical analysis, as well as a column with the statistical difference between both samples. In the final column, we show the coefficient on slaveowner in a bivariate regression within the sample of entrepreneurs.

In the upper panel, we present measures of wealth, including three variables of slave wealth: an indicator function that takes the value of one if the individual is classified as a slaveowner in 1860, the logarithm of slave wealth, and share of slave wealth over personal wealth. ${ }^{8}$ Our theoretical framework and the ability to perform robustness checks motivate us to use three slave wealth variables throughout the analysis. ${ }^{9}$

In the middle panel, we present two measures of human capital: an indicator for illiteracy and age. Following the literature on self-employment and credit access, we use an individual's total wealth and human capital as control variables in our main regressions. An extensive literature has documented the effect of an individual's wealth and human capital on the likelihood of starting a business and gaining access to credit. The theoretical framework we present later also takes into account these intuitive findings. By including these variables as controls in the subsequent analysis, we assure a comparison between individuals with similar wealth and human capital levels.

The final three variables (Baltimore, agro-business, merchant) measure geographic and sectoral composition of the different samples. These variables will be used as controls as well as to perform sub-sample analyses that inform us about the role of slave wealth on business formation in non-slave intensive sectors of the economy.

Table 1 shows some expected patterns. Entrepreneurs are on average richer, have higher human capital, are more likely to be located in Baltimore, tend to work relatively more in non-agricultural sectors, and half of them are merchants (while 25 percent of the IPUMS sample is merchants). The table also shows that approximately 4 percent of the Maryland IPUMS sample is classified as slaveowner, while 13 percent of entrepreneurs are in this category. For comparison with historical accounts of Maryland, it is useful to discuss absolute numbers. A total of 61 individuals in the Maryland IPUMS sample are classified as slaveowner. An average slaveowner in this sample had 7.5 slaves (median of 4). A total of 70 entrepreneurs, on the other hand, are classified as slaveowners. An average slaveowner entrepreneur had 2.5 slaves (median of 2). These

\footnotetext{
${ }^{8}$ More specifically, we use $\log (1+$ wealth measure $)$, as many individuals have recorded values of zero for the different wealth measures.

${ }^{9}$ In particular, using these three variables provides a clear link between the predictions of the model and the empirical results.
} 


\section{Slave Wealth/Entrepreneurship in Civil War Maryland 383}

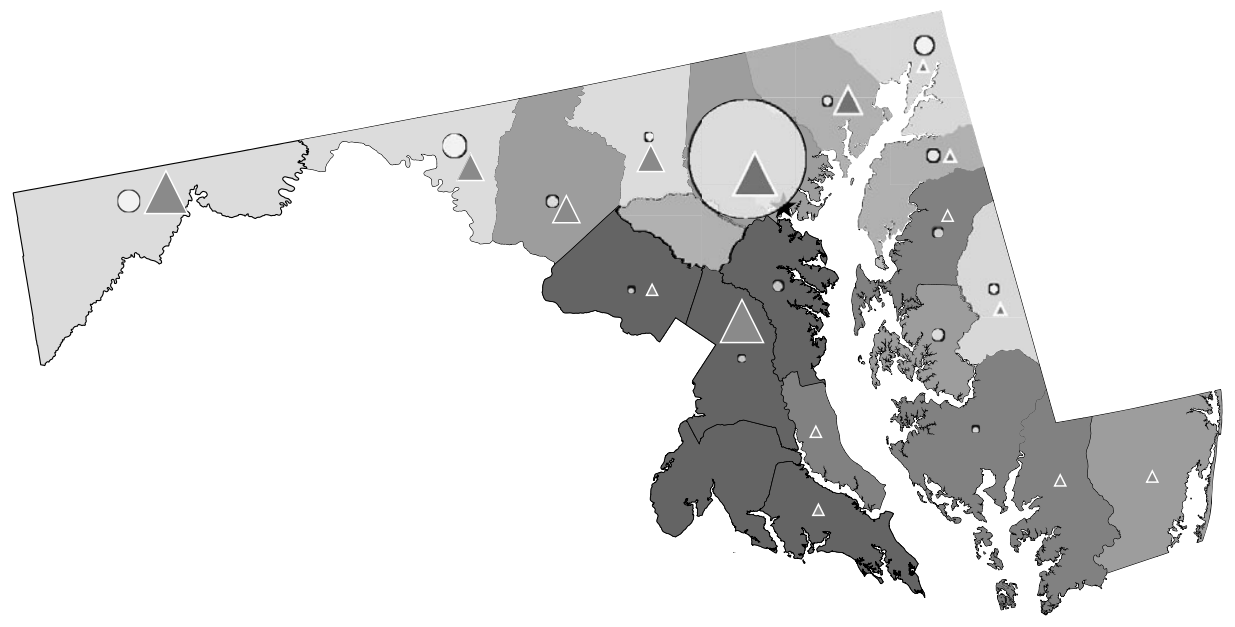

FIGURE 2

LOCATION OF ENTREPRENEURS AND SLAVES

Notes: This map shows the location of slaveowner (triangle) and non-slaveowner (circle) entrepreneurs in our dataset. The size of triangles/circles represent the relative number of entrepreneurs. Most entrepreneurs (approximately 80 percent) are located in Baltimore (marked with a star symbol). In addition, counties with darker colors had more slaves than counties with lighter colors. The source for the number of slaves is the 1860 Slave Schedules.

Source: Authors' calculations.

numbers imply that a total of 621 slaves are implicitly included in our dataset, around 12 percent of all slaves located in Baltimore, as measured by the 1860 Slave Schedules. Slaveowner entrepreneurs are older, likelier to have more real estate wealth, less likely to be in the lowest wealth bin, and more likely to be in the highest wealth bin. Slaveowner entrepreneurs are also less likely to live in Baltimore. Given these significant differences between slaveowner and non-slaveowner entrepreneurs, we control for all these variables in our empirical analysis in order to isolate the effect of slave wealth.

Another important aspect of our dataset is that the majority of entrepreneurs are located in Baltimore, the economic and financial center of Maryland. To offer a sense of their spatial distribution, and their relationship to the overall state slave-economy, Figure 2 presents a map of counties in 1860 Maryland, with the total number of slaves, and the spatial distribution of slaveowner and non-slaveowner entrepreneurs. ${ }^{10}$ This map clearly shows that most of our entrepreneurs are located in the northern part of the state, a pattern that is similar for both slaveowners and nonslaveowners in our sample.

${ }^{10}$ As we do not have the exact location of most entrepreneurs, we simply locate them in approximately the centroid of each county for presentation purposes. 

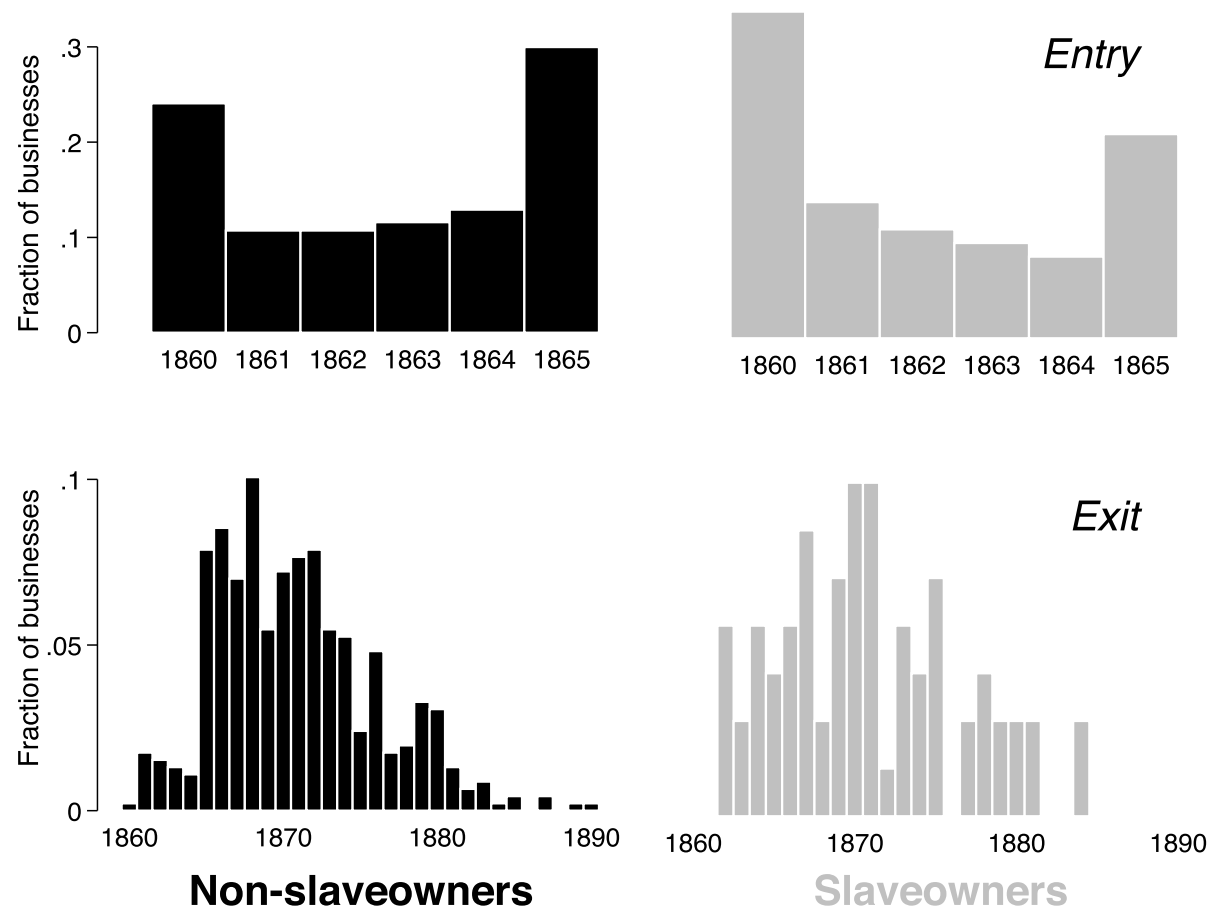

FIGURE 3

BUSINESS ENTRY AND EXIT

Notes: Upper panels show the fraction of businesses that entered between 1860 and 1865. Lower panels show the fraction of businesses that exited between 1860 and 1890. The total number of businesses in our dataset is 526 .

Source: Authors' calculations.

Finally, Figure 3 shows the distribution of the dates of first (entry) and last (exit) reports. The $y$-axis shows the number of entrepreneurs with a first/last report in the date specified in the $x$-axis. Overall, there is a decline in entry after the beginning of the war (1861) and a subsequent increase at the end of it (1865) for both 1860 slaveowners and non-slaveowners, highlighting the importance of the difference relative to overall time effects. We will discuss how the Civil War affects our analysis in the results section, and we already discussed how the slave market did not collapse during this time period. In addition, in the Online Appendix we show that the nominal value of slave sales did not decrease significantly before 1864, suggesting that the slave market was still quite active, and close by markets, such as the one in Alexandria, were still operating. The high slave price might be surprising if slaveowners anticipated emancipation without compensation. Calomiris and Pritchett (2016) show, however, that while slave prices in New Orleans fell in anticipation of 


\section{Slave Wealth/Entrepreneurship in Civil War Maryland 385}

war, the fall was not heterogeneous by slave age and gender, suggesting that this was not due to fear of emancipation in particular so much as fear of war in general. Consistent with this, we would expect to see less of a fall in border states that anticipated not seceding, as shown in the Online Appendix Figure A.3, which uses the Calomiris and Pritchett data. The figure shows that prices for buyers in the border states do not seem to fall in 1860, while prices for slave sales to other states do. As we observe a significant number of first reports after abolition of slavery, this sample serves as a good falsification exercise, which we discuss in the empirical framework section. Panel B is the analogue of Panel A using the last (instead of the first) report. The vast majority of exit occurs after abolition of slavery, and we can actually observe a spike in exit a couple of months after this event. We will use this time variation later on to inform us about mechanisms at work.

\section{THEORETICAL FRAMEWORK}

In this section, we discuss a simple model that is presented in detail in the Online Appendix. The model includes two sets of agents: (1) entrepreneurs seeking start-up funding and (2) suppliers or lenders. An entrepreneur can be either a slaveowner or a non-slaveowner. Slave wealth is allowed to play two different roles: (1) slaveowners could have a relative advantage in using coercion to increase slave productivity (as in Acemoglu and Wolitzky (2011), which we call the "cost of production" channel) and (2) suppliers could prefer slave wealth over other pledgeable assets (e.g., land) due to its higher liquidity (the "collateral" channel). There is a large literature studying how asset liquidity (or redeployability or market tightness) affects the terms of a loan (Williamson 1988; Hart and Moore 1994; Shleifer and Vishny 1992), arguing that loan conditions (e.g., maturity, debt-to-value, promised debt yield) improve with the liquidity of the collateral asset. Efraim Benmelech, Mark J. Garmaise, and Tobias J. Moskowitz (2005) provide evidence from the commercial real estate market that supports these predictions. We examine how business entry and exit decisions are affected when either or both of these channels are active.

In the model, entrepreneurs must exert effort (i.e., complete labor tasks) for their businesses to be successful. Because exerting effort is costly, the loan contract must provide entrepreneurs with sufficient incentives to exert effort. Namely, the loan contract must allow entrepreneurs to keep a sufficiently large fraction of future profits. Providing entrepreneurs with incentives, as a consequence, limits the amount of future 
profits that entrepreneurs can credibly pledge to suppliers, which forces entrepreneurs to pledge assets in addition to future profits for lenders to be willing to supply funds.

\section{Slave Wealth and Business Entry}

In the model, slave wealth may have affected project funding outcomes through both the production and collateral channels. When the cost of production channel is active, the relative advantage in using coercion reduces the cost of effort for slaveowners, allowing slaveowners to credibly pledge more of their future profits, as they require less compensation for exerting effort. Slaveowners, as a result, are required to pledge fewer assets for obtaining project funding because assets and future profits are substitutes. This implies that a slaveowner will obtain project funding with a higher probability than that of an equally-wealthy non-slaveowner when the production channel is active.

When the collateral channel is active, slave wealth is deemed as better collateral by lenders. This is based on the premise that while two assets may have similar "fundamental" values, their relative resale price will be a function of the liquidity (or market tightness) of these assets. The collateral channel implies that a slaveowner will obtain project funding with a higher probability than that of an equally-wealthy non-slaveowner, since the latter must pledge relatively more wealth due to the lower resale value of non-slave wealth.

\section{Abolition and Business Exit}

The model also provides predictions of how the rate of business failure is affected by abolition. In the model, businesses fail with certainty when entrepreneurs do not exert effort. Loan agreements are designed to provide entrepreneurs with sufficient incentives (through a share of the future profits) to exert effort.

We note that loan agreements that were signed before abolition, and that did not make the incentives provided to slaveowners contingent upon abolition, may have failed to provide sufficient incentives to exert effort. This happens because, if the cost of production channel is active, exerting effort becomes more costly to slaveowners after abolition as coerced slaves are no longer available to slaveowners. These lower incentives to exert effort affect the rate of business exit among slaveowners but not among non-slaveowners. 


\section{Slave Wealth/Entrepreneurship in Civil War Maryland 387}

In sum, we obtain three insights from the model. First, both the cost of production and collateral channels imply that, conditional on total wealth, slaveowners are more likely to enter the market because they are required to pledge less wealth than non-slaveowners to obtain project funding. Second, since abolition eliminates any potential benefits from slave wealth, slaveowners and non-slaveowners enter with equal probability after this event. Finally, abolition has an effect on the likelihood of business exit among slaveowners only if the cost of production channel is active. We use these insights to guide our interpretation of the relative importance of these mechanisms.

\section{EMPIRICAL FRAMEWORK}

Following our theoretical framework, we explore the hypothesis of slave wealth having a positive effect on business formation. To test this hypothesis, we compare the rate of business formation among slaveowners and non-slaveowners using (1) individuals who created businesses between January 1860 and December 1865 and (2) a representative sample of people living in Maryland in 1860. We interpret the first set of individuals as entrepreneurs and the second set as a comparison group. We estimate different versions of the following cross sectional regression:

$$
\begin{aligned}
& y_{i}=\alpha+\beta \cdot \text { SlaveWealth }_{i, 1860}+f\left(\text { TotalWealth }_{i, 1860},\right. \\
& \text { RealEstateWealth } \left._{i, 1860}\right)+\gamma^{\prime} X_{i, 1860}+\varepsilon_{i},
\end{aligned}
$$

where $y_{i}$ is an indicator that takes the value of one if individual $i$ created a business before abolition of slavery, and zero otherwise. In addition, $\alpha$ is a constant term, SlaveWealth ${ }_{i, 1860}$ is a measure of slave wealth, $f\left(\right.$ TotalWealth $_{i, 1860}$, RealEstateWealth $_{i, 1860}$ ) is a (flexible) parametric function of total wealth and real estate wealth. The $X_{i, 1860}$ vector includes control variables for human capital (literacy, age, and age-squared) and a Baltimore fixed effect, and $\varepsilon_{i}$ is an error term robust against heteroscedasticity. Under the hypothesis that slave wealth facilitated access to credit, we should observe a higher rate of business formation among individuals with higher levels of slave wealth, even conditional on human capital, total wealth, and real estate wealth, i.e., $\beta>0$.

In some empirical exercises we repeat the earlier analysis using data on business formation after abolition. As slave wealth was destroyed 
after abolition, we expect not to observe an effect of pre-abolition slave wealth on business formation after abolition, i.e., $\beta=0$.

We also perform a sub-sample analysis by restricting attention to (1) individuals located in Baltimore, (2) individuals working in non-agricultural sectors, and (3) merchants. This sub-sample analysis emphasizes the importance of slaves in Maryland's non-agricultural sectors. While we take this as evidence of the collateral channel, the cost of production channel bears on an old debate in the economic history of slavery, on the suitability of slave labor for non-agricultural sectors (Goldin 1976; Bateman and Weiss 1981; Wade 1964). Running the same cross sectional regression in equation (1) in the subsamples allows us to explore the role of the collateral channel in these non-slave intensive sectors.

We address identification concerns in several parts of the results section. Overall, our strategy includes controlling for measures of human capital and all observed differences between slaveowner and non-slaveowner entrepreneurs as well as using a differences-in-differences estimator to control for unobserved differences between slaveowners and non-slaveowners that are time invariant. We also discuss the plausibility of alternative interpretations that cannot be tested directly in our dataset.

\section{RESULTS}

\section{Slave Wealth and Business Formation}

What is the effect of slave wealth on business entry? Our first approach to answer this question is to estimate equation (1) using an indicator for slaveowner as our measure of slave wealth. Columns 1 and 2 in Table 2, panel A, show that conditional on total wealth and real estate wealth, slaveowners were more likely to create businesses than non-slaveowners before abolition. Although this result is consistent with slave wealth being a better form of collateral, it is also consistent with alternative explanations.

A first competing hypothesis is that slaveowners may have had different human capital. However, our controls for human capital do not change the differences in business formation (column 3). ${ }^{11}$ Another competing hypothesis is that, rather than being a good form of collateral, slaves may have given slaveowners a competitive advantage in their cost of production. To address this, we restrict attention to sectors of the

\footnotetext{
${ }^{11}$ We also found that including family size as another human capital control does not affect the differences in business formation among slaveowners and non-slaveowners.
} 
TABLE 2

SLAVEOWNERS AND BUSINESS FORMATION

Dependent variable is an indicator for first report beforelafter abolition of slavery

\begin{tabular}{|c|c|c|c|c|c|c|}
\hline & \multicolumn{3}{|c|}{ All } & \multirow{2}{*}{$\begin{array}{c}\text { Baltimore } \\
\text { (4) }\end{array}$} & \multirow{2}{*}{$\begin{array}{l}\text { Non-agri } \\
\text { (5) }\end{array}$} & \multirow{2}{*}{$\begin{array}{c}\text { Merchants } \\
\text { (6) }\end{array}$} \\
\hline & (1) & (2) & (3) & & & \\
\hline \multicolumn{7}{|l|}{ Panel A: Before } \\
\hline Slaveowner & $\begin{array}{c}0.259 * * * \\
(0.044)\end{array}$ & $\begin{array}{c}0.224 * * * \\
(0.042)\end{array}$ & $\begin{array}{c}0.240 * * * \\
(0.041)\end{array}$ & $\begin{array}{c}0.233 * * * \\
(0.072)\end{array}$ & $\begin{array}{c}0.296 * * * \\
(0.050)\end{array}$ & $\begin{array}{c}0.375 * * * \\
(0.070)\end{array}$ \\
\hline \multicolumn{7}{|l|}{ Panel B: After } \\
\hline Slaveowner & $\begin{array}{c}0.041 \\
(0.028)\end{array}$ & $\begin{array}{c}0.035 \\
(0.030)\end{array}$ & $\begin{array}{c}0.046 \\
(0.028)\end{array}$ & $\begin{array}{c}0.110 \\
(0.068)\end{array}$ & $\begin{array}{c}0.052 \\
(0.039)\end{array}$ & $\begin{array}{l}-0.071 \\
(0.054)\end{array}$ \\
\hline \multicolumn{7}{|l|}{ Panel C } \\
\hline Diff-in-diff & $\begin{array}{c}0.218 * * * \\
(0.060)\end{array}$ & $\begin{array}{c}0.189 * * * \\
(0.057)\end{array}$ & $\begin{array}{c}0.194 * * * \\
(0.058)\end{array}$ & $\begin{array}{c}0.123 \\
(0.134)\end{array}$ & $\begin{array}{c}0.244 * * * \\
(0.079)\end{array}$ & $\begin{array}{c}0.446^{* * *} \\
(0.110)\end{array}$ \\
\hline Flexible wealth control & No & Yes & Yes & Yes & Yes & Yes \\
\hline Human capital controls & No & No & Yes & Yes & Yes & Yes \\
\hline Baltimore & No & No & Yes & No & Yes & Yes \\
\hline Individuals & 2,080 & 2,080 & 2,080 & 1,109 & 1,663 & 493 \\
\hline
\end{tabular}

Notes: Flexible wealth control include the logarithm of real estate wealth and indicators for the following categories: wealth $\in[200,1700]$ (50th and 75 th percentile of the empirical distribution), wealth $\in[1700,10000]$ (75th and 90th percentile), and wealth $>10000$ (the omitted category is wealth $\in[0,200])$. Human capital controls include an indicator variable for illiterate individuals, age, and age squared. Robust standard errors are reported in parentheses (bootstrapped for diff-indiff estimates). Significance level: $* * * p<0.01, * * p<0.05,{ }^{*} p<0.1$.

Source: Authors' calculations.

economy where slaves are less likely to provide a competitive advantage: non-agricultural businesses (column 5) and merchants (column 6 ). We find that, if anything, the effect increases in magnitude in these subsamples, suggesting that the cost of production hypothesis alone is unlikely to explain the empirical relation between slave wealth and business formation.

A third concern is that there were systematic, unobserved differences between slaveowners and non-slaveowners. For example, slaveowners may have differed in political and social connections, saving behavior, and investment opportunities. To address this, we study the link between business formation after abolition and slaveownership in 1860. This analysis should help us understand whether (former) slaveowners were more likely to create businesses even after abolition destroyed their slave wealth. In Table 2, panel B we see that the statistical relationship between slaveownership in 1860 and business formation disappears after abolition, suggesting that slave wealth is more relevant than unobserved differences between slaveowners and non-slaveowners. 
Another, related, concern is that individuals may have chosen to become slaveowners because of the credit market advantage. However, we note that the appraised value of a 25-year-old male slave in Maryland in $1860(\$ 1,350)$ was more than 50 percent of the total wealth of the median entrepreneur - much of which was (illiquid) real estate wealth. Then, it is likely that the median entrepreneur would have required a loan to purchase a slave, giving little reason to believe that the median entrepreneur would have first sought a loan to purchase a slave to then request a different loan to start a business.

We also present the comparison between panels $\mathrm{A}$ and $\mathrm{B}$ using a differences-in-differences estimator before and after abolition. This tests our specific hypothesis that the difference in the coefficients is significant, which is weaker and somewhat different than the test that the coefficients in panel $\mathrm{A}$ is positive and the coefficient in panel $\mathrm{B}$ is zero. We present these results in Table 2, panel $\mathrm{C}$ and find that most of the effect of slaveownership on business entry disappears after abolition; further suggesting that unobserved heterogeneity alone is not driving the result. ${ }^{12}$

In summary, Table 2 shows a robust positive relationship between slaveownership and business formation before abolition and that the relationship disappears after abolition. These results, however, do not exploit heterogeneity in the intensive margin of slave holdings. Our theory suggests that if slave wealth was a better form of collateral, then we should see more business formation among entrepreneurs holding more slave wealth than other equally-wealthy entrepreneurs.

In Table 3 we exploit variation in the amount of slave wealth to explore the relationship between business formation and slave wealth. In columns 1-3 we use the logarithm of slave wealth, while in columns 4-6 we use slave wealth as a fraction of personal wealth. Table 3, panel A studies business formation before the abolition and shows that, conditional on total wealth, an entrepreneur with a higher share of slave wealth is more likely to create a business. As in Table 2, we find that the relationship is robust to controlling for measures of human capital (columns 3 and 6) and to restricting the sample to sectors of the economy where slaves are less likely to provide a competitive advantage (see Table A.3 in the Online Appendix).

In Table 3, panel B we again study business formation after abolition using the slave wealth measures, finding that the positive relationship disappears after abolition. The only exception is in column 6 , where the effect remains statistically significant after abolition, although it decreases

\footnotetext{
${ }^{12}$ See Table A.2 in the Online Appendix for a replication of the results using probit regressions.
} 
TABLE 3

SLAVE WEALTH AND BUSINESS FORMATION

Dependent variable is an indicator for first report beforelafter abolition of slavery

\begin{tabular}{|c|c|c|c|c|c|c|}
\hline & (1) & $(2)$ & $(3)$ & (4) & (5) & (6) \\
\hline \multicolumn{7}{|l|}{ Panel A: Before } \\
\hline Log slave wealth & $\begin{array}{c}0.029 * * * \\
(0.005)\end{array}$ & $\begin{array}{c}0.025^{* * *} * \\
(0.005)\end{array}$ & $\begin{array}{c}0.027 * * * \\
(0.005)\end{array}$ & & & \\
\hline Fraction slave wealth & & & & $\begin{array}{c}0.143 * * * \\
(0.048)\end{array}$ & $\begin{array}{c}0.172 * * * \\
(0.049)\end{array}$ & $\begin{array}{c}0.196^{* * * *} \\
(0.047)\end{array}$ \\
\hline \multicolumn{7}{|l|}{ Panel B: After } \\
\hline Log slave wealth & $\begin{array}{c}0.004 \\
(0.003)\end{array}$ & $\begin{array}{c}0.003 \\
(0.003)\end{array}$ & $\begin{array}{c}0.005 \\
(0.003)\end{array}$ & & & \\
\hline Fraction slave wealth & & & & $\begin{array}{c}0.035 \\
(0.032) \\
\end{array}$ & $\begin{array}{c}0.047 \\
(0.033) \\
\end{array}$ & $\begin{array}{c}0.064 * * \\
(0.032) \\
\end{array}$ \\
\hline \multicolumn{7}{|l|}{ Panel C } \\
\hline Diff-in-diff & $\begin{array}{c}0.025 * * * \\
(0.007)\end{array}$ & $\begin{array}{c}0.022 * * * \\
(0.007)\end{array}$ & $\begin{array}{c}0.022 * * * \\
(0.007)\end{array}$ & $\begin{array}{l}0.108^{*} \\
(0.061)\end{array}$ & $\begin{array}{l}0.125^{*} \\
(0.066)\end{array}$ & $\begin{array}{c}0.132 * * \\
(0.065)\end{array}$ \\
\hline Flexible wealth control & No & Yes & Yes & No & Yes & Yes \\
\hline Human capital controls & No & No & Yes & No & No & Yes \\
\hline Baltimore & No & No & Yes & No & No & Yes \\
\hline Individuals & 2,080 & 2,080 & 2,080 & 2,080 & 2,080 & 2,080 \\
\hline
\end{tabular}

Notes: Flexible wealth control include the logarithm of real estate wealth and indicators for the following categories: wealth $\in[200,1700]$ (50th and 75 th percentile of the empirical distribution), wealth $\in[1700,10000]$ (75th and 90th percentile), and wealth $>10000$ (the omitted category is wealth $\in[0,200])$. Human capital controls include an indicator variable for illiterate individuals, age, and age squared. Robust standard errors are reported in parentheses (bootstrapped for diff-indiff estimates). Significance level: $* * * p<0.01,{ }^{* *} p<0.05,{ }^{*} p<0.1$.

Source: Authors' calculations.

in magnitude. The differences-in-differences estimates are presented in Table 3, panel C, and again suggest that it is slave wealth itself, rather than an unobserved characteristic correlated with slave wealth, that is driving the positive relationship between slave wealth and business formation.

\section{Effect of Civil War}

Despite delayed formal abolition, the Civil War challenged Maryland slavery. Confederate sympathizers fled following passage of martial law in 1861, and those that did not leave were politically persecuted by the occupying Northern army. But they were persecuted as rebels and secessionists, not slaveowners. The Union army did not repress the slave economy during the early years of the occupation, despite widespread dislike of slavery among the troops. In fact, the Union army assisted 
in returning fugitive slaves and even conducted its own slave auctions during the Civil War in Maryland, as well as using slaves owned by loyal slaveowners to assist in the construction of fortifications. Despite this official policy, slaves believed the presence of Union troops slackened slaveowner property rights, and slave insubordination and flight increased with Union army presence. In October 1863, the federal war department passed General Order 329, allowing enlistment of free-blacks, rebelowned slaves, and slaves volunteered by their owners in the border states. However, the enlistment of free-blacks, who were often on indentured labor contracts, raised labor costs enough that many slaveowners began to rely on slaves even more for labor. In addition, owners of enlisted slaves were generously compensated at $\$ 800$ a slave in 1863 , giving them even more liquid stores of wealth.

The interstate slave market thus weakened, but did not collapse during the Civil War. "In 1862, a Frederick County editor was shocked when six young slaves brought a meager total of $\$ 400$ at auction. 'Less than two years ago servants of this description would have commanded $\$ 2,500$,' he fumed. 'The reader will remember that [we] admonished the sympathizers with the rebellion, in advance, that this would be the consequence of the crime and folly of rebellion"' (Grivno 2007, p. 108). The opportunity for slaveowners to sell or mortgage their human chattel still remained after the beginning of the Civil War, albeit at lower prices.

In particular, the rental and hire market for slaves remained active through emancipation. Indeed, even as late as 24 December 1864, the Frederick Examiner newspaper published an ad (paid from 9 July) that stated "To hire: a Negro woman, slave, who is a good cook, washer and ironer and can milk. One preferred without children." While we do not have surviving rental rate data from Maryland, in the Online Appendix we present data from Fogel and Engerman showing volume and price in the Virginia slave hiring market through $1865 .^{13}$

As previously discussed, there are reasons to worry about a differential impact of the Civil War on business formation by slave ownership status. However, historical evidence and data on slave sales shown in the Online Appendix (Figure A.1) suggest the slave market was active even in 1863, two years after the beginning of the war. In order to analyze the effect of the Civil War on the differential rates of business formation, we divide the sample in three periods and repeat the analysis in the previous subsection.

${ }^{13}$ The correlation between residualized rental rates in Maryland and Virginia in the decade before the Maryland data ends (1845-1855) is 0.66 , which suggests the markets were integrated to some degree. 


\section{Slave Wealth/Entrepreneurship in Civil War Maryland 393}

The three periods we use are defined as follows. The before period includes all businesses created between January 1860 and April 1861, before the beginning of the Civil War. The during period includes all businesses created between April 1861 and November 1864, after the beginning of the Civil War but before abolition of slavery. Finally, the after sample includes all businesses created between December 1864 and December 1865, after abolition. We pool the years between 1861 and 1863 for precision, as Figure 3 shows that there are many fewer businesses started per year, by both slaveowners and non-slaveowners, in these war years.

Table 4 presents results of our main estimating equation using business formation in each period as dependent variable. The relationship between slave wealth and business formation during the Civil War remained as strong as before the beginning of the Civil War. The coefficient on slave wealth after the Civil War decreases in magnitude relative to the before estimate in panels $\mathrm{A}-\mathrm{C}$, suggesting that most of the decline in the differential rate of business formation was a consequence of abolition rather than of the beginning of the Civil War. The positive, if unstable, point estimate of slave wealth after abolition might reflect the importance of unobservable variables correlated with slave wealth (e.g., network connections). As discussed earlier, the Civil War did not destroy slavery in Maryland until 1864, and indeed the payment for enlisted slaves may have kept slave wealth even more valuable than the 1860 price would indicate even through the war.

\section{Indirect Evidence}

In this final subsection we complement our analysis providing indirect evidence that the collateral channel, and not the cost of production channel, was the mediating factor behind the observed empirical relation between slave wealth and business formation.

\section{SLAVE WEALTH AND EXIT}

One of the insights from our theoretical framework is that if entrepreneurs had a relative advantage in coercing slaves to lower their cost of production, then we should observe a higher rate of exit among slaveowners after abolition of slavery. This is due to abolition increasing the cost of production for slaveowners and, consequently, reducing the incentives to exert effort. Comparing post-abolition attrition rates, therefore, provides a test for the cost of production channel. One could argue, however, that this is not a perfect test because pledging assets may have 
TABLE 4

SLAVE WEALTH AND BUSINESS FORMATION BEFORE AND DURING THE CIVIL WAR

Dependent variable is an indicator for first report in period $X$

\begin{tabular}{|c|c|c|c|c|c|c|}
\hline & \multirow{2}{*}{$\begin{array}{c}\text { Before Civil War } \\
\text { (Jan '60-Apr '61) } \\
\text { (1) }\end{array}$} & \multirow{2}{*}{$\begin{array}{c}\text { During Civil War } \\
\text { (May '60-Nov '64) } \\
\text { (2) }\end{array}$} & \multirow{2}{*}{$\begin{array}{c}\text { After Abolition } \\
\text { (Nov'64-Dec '65) } \\
\text { (3) }\end{array}$} & \multicolumn{3}{|c|}{ Differences-in-differences } \\
\hline & & & & $(1)-(2)$ & (1)-(3) & $(2)-(3)$ \\
\hline Slaveowner & $\begin{array}{c}0.108 * * * \\
(0.034)\end{array}$ & $\begin{array}{c}0.127 * * * \\
(0.037)\end{array}$ & $\begin{array}{l}0.048 * \\
(0.028)\end{array}$ & $\begin{array}{l}-0.019 \\
(0.058)\end{array}$ & $\begin{array}{c}0.060 \\
(0.049) \\
\end{array}$ & $\begin{array}{c}0.079 \\
(0.052)\end{array}$ \\
\hline \multicolumn{7}{|l|}{ Panel B } \\
\hline Log slave wealth & $\begin{array}{c}0.012 * * * \\
(0.004)\end{array}$ & $\begin{array}{c}0.014 * * * \\
(0.004)\end{array}$ & $\begin{array}{c}0.005 \\
(0.003)\end{array}$ & $\begin{array}{l}-0.002 \\
(0.007)\end{array}$ & $\begin{array}{c}0.007 \\
(0.005)\end{array}$ & $\begin{array}{c}0.009 \\
(0.006)\end{array}$ \\
\hline \multicolumn{7}{|l|}{ Panel C } \\
\hline Fraction slave wealth & $\begin{array}{c}0.095 * * * \\
(0.035)\end{array}$ & $\begin{array}{c}0.097 * * \\
(0.039)\end{array}$ & $\begin{array}{c}0.067 * * \\
(0.032)\end{array}$ & $\begin{array}{l}-0.002 \\
(0.057)\end{array}$ & $\begin{array}{c}0.028 \\
(0.050)\end{array}$ & $\begin{array}{c}0.030 \\
(0.056)\end{array}$ \\
\hline Mean of dep. variable & 0.064 & 0.116 & 0.073 & - & - & - \\
\hline Human capital controls & Yes & Yes & Yes & Yes & Yes & Yes \\
\hline Baltimore & Yes & Yes & Yes & Yes & Yes & Yes \\
\hline
\end{tabular}

Notes: Flexible wealth control include the logarithm of real estate wealth and indicators for the following categories: wealth $\in$ [200, 1700] (50th and 75th percentile of the empirical distribution), wealth $\in[1700,10000]$ (75th and 90th percentile), and wealth $>10000$ (the omitted category is wealth $\in[0$, 200]). Human capital controls include an indicator variable for illiterate individuals, age, and age squared. Robust standard errors are reported in parentheses (bootstrapped for diff-in-diff estimates). *** $p<0.01$, ** $p<0.05, * p<0.1$.

Source: Authors' calculations. 


\section{Slave Wealth/Entrepreneurship in Civil War Maryland 395}

been as important for establishing credit relations than for keeping those relations active. We argue that this is not the case as we find that higher levels of total wealth are not significantly correlated with the probability of exit after abolition but they are so for the probability of entry (both before and after abolition).

Based on these ideas, we test for whether slave property rights provided a cost of production advantage by comparing the post-abolition attrition rate between (former) slaveowners and non-slaveowners. We make use of the subsample of businesses that were created before abolition and that were operating immediately after abolition (i.e., the date of business exit is after November 1864). ${ }^{14}$ Using this sample, we ran regressions similar to those reported in Table 2, but replacing the dependent variable for an indicator that takes the value of one if the date of business exit was within a year after abolition. ${ }^{15}$

Table 5 presents regression results from these exercises using the same table taxonomy we have been using throughout our analysis. Panel A shows that there was no statistically significant relationship between slaveownership and exiting following abolition. In fact, if anything, slaveowners were less likely to exit during this time period. Importantly, note that we are controlling for total wealth, so this result cannot be attributed to the fact that slaveowners were wealthier. Panels B and C use our alternative measures of slave wealth and the results are similar, suggesting that slave and non-slaveowner entrepreneurs did not present differential exit rates within one year of abolition.

Finally, since one may be concerned that some of these exits may be relocation of businesses across state lines rather than business failures, we restrict the sample to entrepreneurs that were living in Maryland both in 1860 and 1870 (column 7). ${ }^{16}$ We find that restricting attention to this subsample does not affect the result.

Overall, using the insights gained from the model, we can take both the business formation and exit results to conclude that the collateral mechanism was more likely to be the channel at work. Although we acknowledge that analyzing differential rates of exit is by no means a perfect test for the cost of production channel, we believe this is suggestive evidence of the collateral mechanism being relatively more important.

\footnotetext{
${ }^{14}$ There are a total of 331 businesses that meet these criteria.

${ }^{15}$ Approximately 11 percent of operating businesses have a last report in this window of time. In Table A.5 in the Online Appendix we repeat this exercise with exit during 1864 or 1865 as our dependent variable.

${ }^{16}$ The subsample in column 7 is the set of entrepreneurs with a name-county-age match in Maryland in the 1870 U.S. Population Census.
} 
TABLE 5

SLAVE WEALTH AND EXIT AFTER ABOLITION

Dependent variable is an indicator for last report one year within abolition of slavery

\begin{tabular}{|c|c|c|c|c|c|c|c|}
\hline & \multicolumn{3}{|c|}{ All } & \multirow{2}{*}{$\begin{array}{c}\text { Baltimore } \\
\text { (4) }\end{array}$} & \multirow{2}{*}{$\begin{array}{c}\text { Non-agri } \\
\text { (5) }\end{array}$} & \multirow{2}{*}{$\begin{array}{c}\text { Merchants } \\
\text { (6) }\end{array}$} & \multirow{2}{*}{$\begin{array}{c}\text { MD } 1870 \\
\text { (7) }\end{array}$} \\
\hline & (1) & (2) & (3) & & & & \\
\hline \multicolumn{8}{|l|}{ Panel A } \\
\hline Slaveowner & $\begin{array}{l}-0.049 \\
(0.042)\end{array}$ & $\begin{array}{c}-0.043 \\
(0.043)\end{array}$ & $\begin{array}{c}-0.034 \\
(0.044)\end{array}$ & $\begin{array}{c}-0.058 \\
(0.058)\end{array}$ & $\begin{array}{l}-0.036 \\
(0.046)\end{array}$ & $\begin{array}{c}-0.039 \\
(0.052)\end{array}$ & $\begin{array}{c}0.003 \\
(0.025)\end{array}$ \\
\hline \multicolumn{8}{|l|}{ Panel B } \\
\hline Log slave wealth & $\begin{array}{l}-0.007 \\
(0.005)\end{array}$ & $\begin{array}{l}-0.006 \\
(0.005)\end{array}$ & $\begin{array}{l}-0.005 \\
(0.005)\end{array}$ & $\begin{array}{l}-0.007 \\
(0.007)\end{array}$ & $\begin{array}{l}-0.005 \\
(0.006)\end{array}$ & $\begin{array}{c}-0.005 \\
(0.0067)\end{array}$ & $\begin{array}{c}0.001 \\
(0.003)\end{array}$ \\
\hline \multicolumn{8}{|l|}{ Panel C } \\
\hline Fraction slave wealth & $\begin{array}{c}-0.021 \\
(0.064)\end{array}$ & $\begin{array}{c}-0.031 \\
(0.066)\end{array}$ & $\begin{array}{c}-0.003 \\
(0.067)\end{array}$ & $\begin{array}{c}0.017 \\
(0.109)\end{array}$ & $\begin{array}{c}-0.001 \\
(0.071)\end{array}$ & $\begin{array}{c}0.029 \\
(0.097)\end{array}$ & $\begin{array}{l}-0.030 \\
(0.036)\end{array}$ \\
\hline Flexible wealth control & No & Yes & Yes & Yes & Yes & Yes & Yes \\
\hline Human capital controls & No & No & Yes & Yes & Yes & Yes & Yes \\
\hline Observations & 331 & 331 & 331 & 259 & 319 & 159 & 43 \\
\hline
\end{tabular}

Notes: Flexible wealth control include the logarithm of real estate wealth and indicators for the following categories: wealth $\in$ [200, 1700] (50th and 75th percentile of the empirical distribution), wealth $\in[1700,10000]$ (75th and 90th percentile), and wealth $>10000$ (the omitted category is wealth $\in[0,200]$ ). Human capital controls include an indicator variable for illiterate individuals, age, and age squared. Robust standard errors are reported in parentheses. Significance level: *** $p<0.01, * * p<0.05, * p<0.1$.

Source: Authors' calculations. 


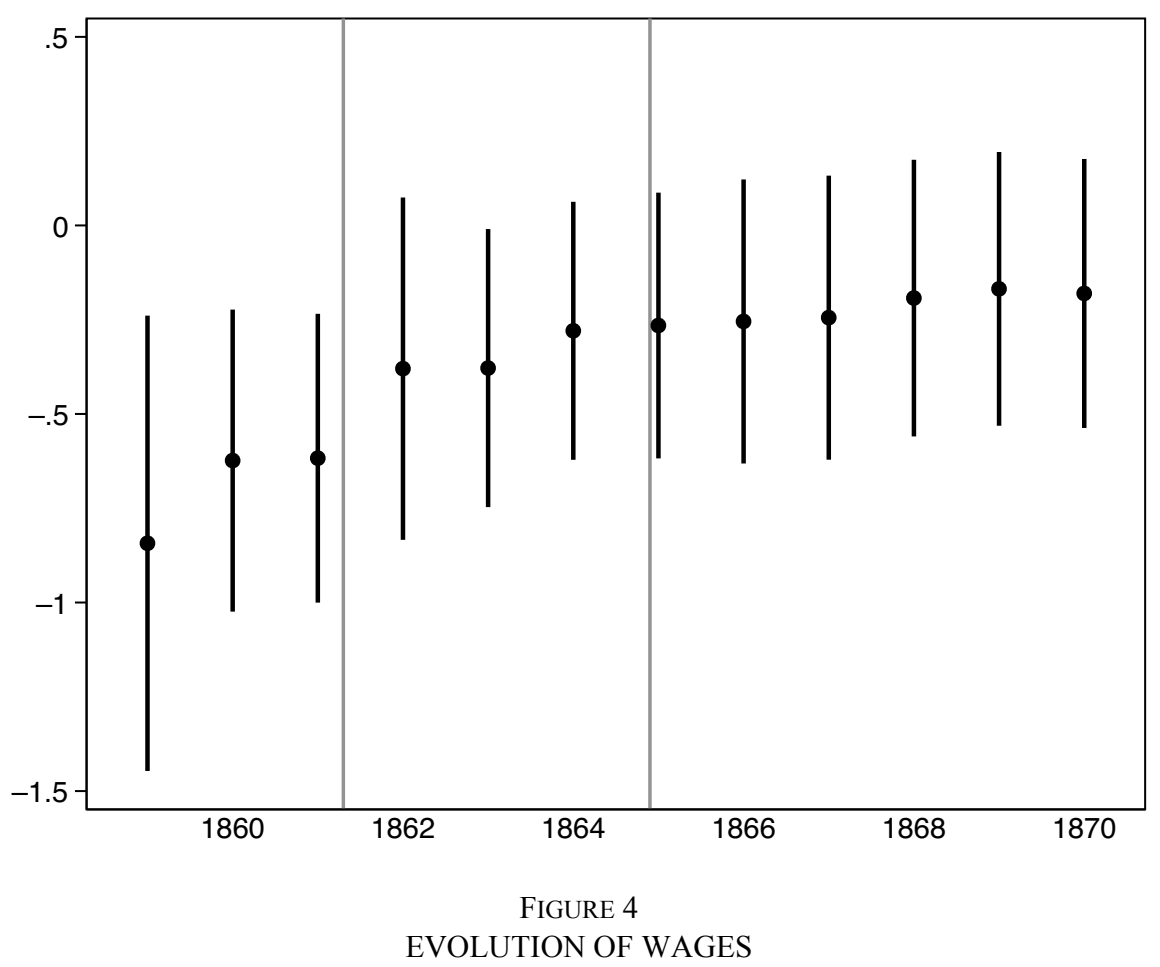

Notes: In this figure we report coefficients on year fixed effects from a regression of log daily wages in Maryland on gender, age, city, and year fixed effects using data from Meyer (2004). Source: Authors' calculations.

WAGES

We next examine the labor market in Maryland to complement our evidence that the collateral channel was the relevant channel through which slave wealth affected business formation. In particular, we study how wages changed before and after abolition using a sample of workers from the Weeks report (Weeks 1886; Meyer 2004). The data include white male and female workers in Maryland. We normalize wages to be expressed in daily units.

To analyze the evolution of wages over time, we regress log daily wage on a gender indicator, a child indicator, city fixed effects, and year fixed effects. We restrict our analysis to the years after 1855 and report the coefficients for the year fixed effects in Figure 4. As can be seen, we find no significant changes in the first years after abolition. This evidence suggests that abolition did not significantly change the labor market equilibrium.

A potential explanation for this pattern of unaltered wages is that slaves were already working for market wages prior to abolition, except the 
wages were paid as rent to the slaveowner. If this was the case, the supply of workers seeking wages should have remained unchanged after abolition, leaving the equilibrium wage unaffected. We previously argued that the rental market was functioning well into 1864 in Maryland. In the Online Appendix we also show that there was no significant trend in the monthly rental rates of slaves in nearby Virginia, suggesting a stable hiring market equilibrium there despite the threats to adjacent Maryland slave property, the ongoing Civil War, and even the 1863 emancipation proclamation. All together, we interpret these findings as additional evidence that the collateral channel was how slave wealth affected business formation. That is, ownership of slaves was not necessary to obtain the productive advantages of slave labor.

\section{NARRATIVE EVIDENCE}

We can also find qualitative evidence that the collateral channel was important in Maryland. An example of private credit collateralized with slaves can be found in Peter J. DePuydt (2013), which discusses the case of politician Outerbridge Horsey and John Lee, two Maryland slaveowners who, in 1828, mortgaged 65 of their slaves to the Linton household and Mr. Johnson in an effort to purchase a Louisiana sugar plantation. Their anticipated sugar profits failed to materialize, however, and the pair wound up mortgaging even more slaves to finance their losing operation. Surviving mortgage documents allow us to see the slaves mortgaged, and Online Appendix Figure A.5 shows the distribution by age and sex, and shows that prime age males formed the bulk of the collateral. In the end, Linton and Johnson successfully sued Horsey and Lee for the debts owed, which resulted in forced sales of the mortgaged people and purchased plantation by the court.

Another source of evidence for the importance of slavery to credit relationships in Maryland is court records. Jenny B. Wahl (1996) argues that antebellum southern slave law converged on efficient rules for renting and selling slaves. Legislation in Maryland explicitly classified slaves as personal property and gave standards for mortgages that pledged such property as collateral. In Wahl's data, a large share of the cases in Maryland are for "transfer": either inheritance, divorce, or for repayment of an obligation - such as a debt or a loan. Many Maryland cases appearing in the records of higher courts, such as Lee v. Pindle (1842) and Denton v. Griffith (1861), where five slaves were mortgaged for $\$ 1,500$, pit widows against creditors in courts over ownership of estate slaves. In Bruce v. Levering (1865), an 1861 mortgage, worth $\$ 1,066$ in 1865 , was 


\section{Slave Wealth/Entrepreneurship in Civil War Maryland}

foreclosed. The total value of the collateral posted was $\$ 981$ but the two slaves pledged, worth $\$ 180$, had been emancipated, so the court ruled that the creditor only held rights to $\$ 781$.

The negative effect expropriation of collateralized slave wealth would have on financial contracts was well-understood at the time. Slave mortgages were invoked as an argument against abolition during the Maryland Constitutional Convention of 1864 . Given legal precedents that ruled that exempting property pledged as collateral annulled the mortgage contract, one representative argued that the constitutional protection of contracts implied that abolition was unconstitutional, declaring "there is no security for the debt in the mortgage except Negroes. They are emancipated. The contract is that the Negroes shall pay the debt. The act of the legislature destroys that contract" (Lord 1864, p. 734).

\section{ALTERNATIVE EXPLANATIONS}

Of course, slaveowners are potentially different in many dimensions, even conditional on wealth. Political power, social connections and prestige, savings behavior, and access to investment opportunities may all have been different for slaveowners in 1860. This highlights the usefulness of our differences-in-differences approach, which compares 1860 slaveowners before and after abolition. But this does not rule out potentially time-varying sources of heterogeneity. While we think slaveowner social connections are unlikely to suddenly change immediately after emancipation, an important unobservable variable is slaveowner political power, which may have been altered with the destruction of slave property. While the next election after 1864 was not until 1866, after our sample period, the political fall of ex-slaveowners may have begun earlier. But this is unlikely, both because slaveowners owned a considerable amount of land, and because there was no political revolution in Maryland. As a member of the Union, Maryland was spared any forced Reconstruction and associated franchise extension. Indeed, the legislature rejected extending the franchise to blacks in 1867, and indeed was only forced to do so in 1870 by the 15th Amendment.

Another concern is that there is general economic turmoil associated with the Civil War that is differentially affecting slaveowners before and after 1864 . We document that slaveowner entry remains significantly higher through 1864 and the coefficient on fraction slave wealth remains large and positive during the war. In addition, by focusing on slave wealth as conditional on other real wealth such as land, we can rule out differential inflation effects. It still could be the case that the much larger 
inflation in the South may have affected the market for slaves differentially. The financial shocks of the National Banking Act and the large number of bank closures induced may have also affected slave wealth differentially, but banks had little to do with smaller entrepreneurial businesses. Of course, there are shocks we cannot rule out, for example, that the anticipated collapse of the South in 1865 may have mattered more than emancipation in reducing the value of slaves, but this is broadly consistent with the mechanisms in our article.

A final concern is differential out-migration. Tables A.5-A.7 in the Online Appendix also show that our results are not driven by differential outmigration from Maryland. We restrict attention to individuals we can link to the full-count 1870 census, and who are in Maryland in both 1860 and 1870 . While our sample size and precision necessarily falls, the coefficients remain positive and large on entry, with again no differences in exit (column 7 in Table A.7).

\section{CONCLUSION}

This article explores a new dimension of the economic effects of slavery. While most of the economic literature has focused on slaves as labor force, we explore how slave wealth facilitated business start-ups as a liquid, high-quality source of collateral.

Our main empirical result is that entrepreneurs with more slave wealth were more likely to enter into the market than equally-wealthy entrepreneurs with other types of wealth, suggesting that wealth composition and wealth liquidity were relevant factors behind business start-ups. We find that this relationship disappears post-abolition, suggesting that slave wealth, as opposed to unobserved characteristics of former slaveowners, is what drives this result. While our context is not representative of the bulk of the slave economy, and emancipation was during a volatile period, Maryland's relatively sophisticated economy and unique position during the Civil War makes our empirical finding an informative first step in exploring the collateral dimensions of the slave economy.

Our results are relevant for many debates around slavery. An interesting implication is that some of the returns to scale believed to be the source of slave productivity may have been due to improved access to credit rather than solely the gang-labor production process. A financial perspective on slavery also adds a new dimension to the costs of the Civil War and the long period of subsequent economic backwardness experienced in the postbellum South. Slaveowners lost not just the war and the extra hours of uncompensated black toil, but also their primary store of 


\section{Slave Wealth/Entrepreneurship in Civil War Maryland 401}

value. In Maryland, one of the largest insurance sellers, the Baltimore Life Insurance company, specialized in slave life insurance, and was forced out of business in 1867 (Murphy 2005). Kilbourne (1995) shows a drastic credit contraction in East Feliciana, and an increased reliance on cotton liens as a credit instrument. Assessing the long-term damage wreaked by emancipation on regional Southern balance sheets and credit networks (including the rise of the general store as a substitute credit mechanism as in Ransom and Sutch (1988)) may be a useful direction for future research. ${ }^{17}$ If settling financial obligations, including via foreclosure and court-ordered sales, increased the incidence of slave trading, then the human costs of family separation borne by African Americans under slavery loom even larger. Indeed, Upper South slaves likely lived in heightened fear of forced sale to the Deep South when their owners were highly indebted.

Enslaved people themselves understood the role creditors played in the system. Moses Grandy's brother and wife were both sold because their owners found themselves in debt. Grandy subsequently wrote that "proprietors, though they live in luxury, generally die in debt....At the death of a proprietor, it commonly happens that his coloured people are sold towards paying his debts. So it must and will be with masters, while slavery continues" (Grandy 1843).

The financial role of slaves is also informative for recent debates about "capital" as a physical input versus capital as a financial asset. For example, Thomas Piketty (2014) discusses the question of whether slaves should be considered a component of capital, or just a financial obligation owed by the slaves to the slaveowners. But the business collateral channel suggests that slave property rights may have been productive, facilitating projects that would have not otherwise secured financing, and thus may not simply be financial obligations that net out to zero at the social level. ${ }^{18}$ The bodies and skills of African-Americans were, in the antebellum South, capital in virtually all economically relevant dimensions, including financial dimensions.

Finally, our results emphasize that slave property rights were relevant to much more than plantation agriculture alone. Maryland, economically much closer to the free states than the slave states, still made use of slaves in ways that were complementary to modern, industrial activities. While

\footnotetext{
${ }^{17}$ A Brazilian analogue can be found in Schulz (2008), who describes the effects of abolition in Brazil on credit and money supply, arguing that the government inflated the economy and allowed loose financial regulation for rural banks as a way to placate the slaveowners after abolition.

${ }^{18}$ Piketty argues that slaves were indeed capital, and not "human capital," because slave labor could be alienated and sold on markets.
} 
slaves employed in industry were likely still rare, the role slaves played as collateral suggests that slaves may have been pledged in even more complex and extensive financial contracts, extending onto the balance sheets of Northern institutions. Slavery had economic consequences far beyond plantation agriculture, and may be a larger contributor to national economic development than previously thought.

\section{REFERENCES}

Acemoglu, Daron, and Alexander Wolitzky. "The Economics of Labor Coercion." Econometrica 79, no. 2 (2011): 555-600.

Bateman, Fred, and Thomas Weiss. A Deplorable Scarcity: The Failure of Industrialization in the Slave Economy. Chapel Hill: University of North Carolina Press, 1981.

Benmelech, Efraim, Mark J. Garmaise, and Tobias J. Moskowitz. "Do Liquidation Values Affect Financial Contracts? Evidence from Commercial Loan Contracts and Zoning Regulation." Quarterly Journal of Economics 120, no. 3 (2005): $1121-54$.

Besley, Timothy, and Maitreesh Ghatak. "Property Rights and Economic Development." In Handbook of Development Economics, Vol. 5, edited by Dani Rodrik and Mark Rosenzweig, 4525-95. Amsterdam: Elsevier, 2010.

Blanchflower, David G., and Andrew J. Oswald. "What Makes an Entrepreneur?" Journal of Labor Economics 16, no. 1 (1998): 26-60.

Brennecke, Claire. "Information Acquisition in Antebellum U.S. Credit Markets." Unpublished Manuscript, 2014.

Calderhead, William. "How Extensive Was the Border State Slave Trade? A New Look." Civil War History 17 (1972): 42-55.

Calomiris, Charles W., Mauricio Larrain, José Liberti, et al. "How Collateral Laws Shape Lending and Sectoral Activity." Journal of Financial Economics 123, no. 1 (2015): 163-88.

Calomiris, Charles W., and Jonathan Pritchett. "Betting on Secession: Quantifying Political Events Surrounding Slavery and the Civil War." American Economic Review 106, no. 1 (2016): 1-23.

Campello, Murillo, and Mauricio Larrain. "Enlarging the Contracting Space: Collateral Menus, Access to Credit, and Economic Activity." Review of Financial Studies 29, no. 2 (2015): 349-83.

De Soto, Hernando. The Mystery of Capital: Why Capitalism Triumphs in the West and Fails Everywhere Else. New York, NY: Basic Books, 2003.

DePuydt, Peter J. "The Mortgaging of Souls: Sugar, Slaves, and Speculation." Louisiana History 54, no. 4 (2013): 448-64.

Deyle, Steven. "The Domestic Slave Trade in America: The Lifeblood of the Southern Slave System." In The Chattel Principle: Internal Slave Trades in the Americas, edited by Walter Johnson, 91-116. New Haven, CT: Yale University Press, 2005.

Dunn, Thomas, and Douglas Holtz-Eakin. "Financial Capital, Human Capital, and the Transition to Self-Employment: Evidence from Intergenerational Links." Journal of Labor Economics 18, no. 2 (2000): 287-305. 


\section{Slave Wealth/Entrepreneurship in Civil War Maryland 403}

Evans, David S., and Boyan Jovanovic. "An Estimated Model of Entrepreneurial Choice under Liquidity Constraints." Journal of Political Economy 97, no. 4 (1989): 808-27.

Evans, David S., and Linda S. Leighton. "Some Empirical Aspects of Entrepreneurship." American Economic Review 79, no. 3 (1989): 519-35.

Fairlie, Robert W. "The Absence of the African American Owned Business: An Analysis of the Dynamics of Self-Employment." Journal of Labor Economics 17, no. 1 (1999): 80-108.

Fairlie, Robert W., and Harry A. Krashinsky. "Liquidity Constraints, Household Wealth, and Entrepreneurship Revisited." Review of Income and Wealth 58, no. 2 (2012): 297-306.

Field, Erica, and Maximo Torero. "Do Property Titles Increase Credit Access Among the Urban Poor?" Unpublished Manuscript, 2008.

Fields, Barbara J. Slavery and Freedom on the Middle Ground. New Haven, CT: Yale University Press, 1984.

Fogel, Robert W., and Stanley L. Engerman. Time on the Cross: The Economics of American Negro Slavery. Boston: Little, Brown and Company, 1974.

- Slave Sales and Appraisals, 1775-1865. Rochester, NY: University of Rochester [producer]. Ann Arbor, MI: Inter-University Consortium for Political and Social Research [producer and distributor], 1976.

Frederick Examiner, November 1858.

Galiani, Sebastian, and Ernesto Schargrodsky. "Property Rights for the Poor: Effects of Land Titling." Journal of Public Economics 94, no. 9-10 (2010): 700-29.

Goldin, Claudia. Urban Slavery in the American South 1820-1860: A Quantitative History. Chicago: University of Chicago Press, 1976.

Grandy, Moses. Narrative of the Life of Moses Grandy; Late a Slave in the United States of America. Chapel Hill: University of North Carolina, 2011 (1843).

Greenwald, Bruce C., and Robert R. Glasspiegel. "Adverse Selection in the Market for Slaves: New Orleans, 1830-1860.” Quarterly Journal of Economics 98, no. 3 (1982): 479-99.

Grivno, Max L. “'There Slavery Cannot Dwell': Agriculture and Labor in Northern Maryland, 1790-1869." Ph.D. thesis, University of Maryland, 2007.

Hart, Oliver, and John Moore. "A Theory of Debt Based on the Inalienability of Human Capital." Quarterly Journal of Economics 109, no. 4 (1994): 841-79.

Holtz-Eakin, Douglas, David Joulfaian, and Harvey S. Rosen. "Sticking It Out: Entrepreneurial Survival and Liquidity Constraints." Journal of Political Economy 102, no. 1 (1994): 53-75.

Holtz-Eakin, Douglas, and Harvey S. Rosen, eds. Public Policy and the Economics of Entrepreneurship. Cambridge, MA: The MIT Press, 2004.

Hurst, Erik G., and Annamaria Lusardi. "Liquidity Constraints, Household Wealth, and Entrepreneurship." Journal of Political Economy 58, no. 2 (2004): 279-306.

Johansson, Edvard. "Self-Employment and Liquidity Constraints: Evidence from Finland." Scandinavian Journal of Economics 102, no. 1 (2000): 123-34.

Johnson, Walter. River of Dark Dreams: Slavery and Empire in the Cotton Kingdom. Cambridge, MA: Belknap Press, 2013.

Kilbourne, Richard H. Debt, Investment, Slaves: Credit Relations in East Feliciana Parish, Louisiana, 1825-1885, 1st Edition. Tuscaloosa, AL: University Alabama Press, 1995. 
Levy, Jonathan. Freaks of Fortune: The Emerging World of Capitalism and Risk in America. Cambridge, MA: Harvard University Press, 2012.

Lindh, Thomas, and Henry Ohlsson. "Self-Employment and Windfall Gains: Evidence from the Swedish Lottery." The Economic Journal 106, no. 439 (1996): 1515-26.

_. "Self-Employment and Wealth Inequality." Review of Income and Wealth 44, no. 1 (1998): 25-41.

Lord, Wm. Blair. Debates of the Constitutional Convention of the State of Maryland, volume 1. Annapolis, MD: Richard P. Bayly, 1864.

Madison, James H. "The Evolution of Commercial Credit Reporting Agencies in Nineteenth-Century America." Business History Review 48, no. 2 (1974): 164-86.

Martin, Bonnie. "Slavery's Invisible Engine: Mortgaging Human Property." Journal of Southern History 76, no. 4 (2010): 817-66.

Maryland, Vols. 2, 7, 8 and 9, R.G. Dun \& Company Collection. Boston, MA: Baker Library Historical Collections, Harvard Business School, no date.

Meyer, Bruce. "Why Are There So Few Black Entrepreneurs?" NBER Working Paper No. 3537, Cambridge, MA, December 1990.

Meyer, P. B. “The Weeks Report Database.” Unpublished Manuscript, 2004. Available at http://www.nber.org/papers/w3537.

Morris, Richard B. "Labor Controls in Maryland in the Nineteenth Century." Journal of Southern History 14 (1948): 385-400.

Murphy, Sharon A. "Securing Human Property: Slavery, Life Insurance, and Industrialization in the Upper South." Journal of the Early Republic 25, no. 4 (2005): 615-52.

Norris, James D. R.G. Dun and Co. 1841-1900, The Development of Credit-Reporting in the Nineteenth Century. Westport, CT: Greenwood Press, 1978.

Nykvist, Jenny. "Entrepreneurship and Liquidity Constraints." Scandinavian Journal of Economics 110, no. 1 (2008): 23-43.

Olegario, Rowena. A Culture of Credit: Embedding Trust and Transparency in American Business. Cambridge, MA: Harvard University Press, 2006.

Piketty, Thomas. Capital in the Twenty-First Century. Cambridge, MA: Belknap Press, 2014.

Priest, Claire. "The End of Entail: Information, Institutions, and Slavery in the American Revolutionary Period." Law and History Review 33, no. 2 (2015): 277-319.

Pritchett, Jonathan B. "Quantitative Estimates of the United States Interregional Slave Trade, 1820-1860.” Journal of Economic History 61, no. 3 (2001): 467-75.

Ransom, Roger, and Richard Sutch. "Capitalists without Capital: The Burden of Slavery and the Impact of Emancipation.” Agricultural History 62, no. 3 (1988): 133-60.

Ruggles, Steven, J. Trent Alexander, Katie Genadek, et al. Integrated Public Use Microdata Series: Version 5.0 [Machine-readable database]. Minneapolis: University of Minnesota, 2010.

Schulz, John. The Financial Crisis of Abolition. New Haven, CT: Yale University Press, 2008.

Shleifer, Andrei, and Robert W. Vishny. "Liquidation Value and Debt Capacity: A Market Equilibrium Approach.” Journal of Finance 47, no. 4 (1992): 1343-66.

Steckel, Richard, and Nicolas L. Ziebarth. "A Troublesome Statistic: Traders and the Westward Movement of Slaves.” Journal of Economic History 73, no. 3 (2013): 792-809. 


\section{Slave Wealth/Entrepreneurship in Civil War Maryland 405}

Tadman, Michael. Speculators and Slaves: Masters, Traders, and Slaves in the Old South. Madison, WI: University of Wisconsin Press, 1990.

Taylor, Mark P. "Self-Employment and Windfall Gains in Britain: Evidence from Panel Data." Economica 68, no. 272 (2001): 539-65.

Wade, Richard C. Slavery in the Cities: The South, 1820-1860. New York: Oxford University Press, 1964.

Wahl, Jenny B. “American Slavery and the Path of the Law." Social Science History 20, no. 2 (1996): 281-316.

Weeks, Joseph D. Report on the Statistics of Wages in Manufacturing Industries. Washington, D.C.: GPO, 1886.

Williamson, Oliver E. "Corporate Finance and Corporate Governance." Journal of Finance 43, no. 3 (1988): 567-91.

Wright, Gavin. Slavery and American Economic Development. Baton Rouge, LA: Louisiana State University Press, 2006.

Wyatt-Brown, Bertram. "God and Dun \& Bradstreet, 1841-1851.” Business History Review 40, no. 4 (1966): 432-50.

Zissimopolous, Julie, and Lynn Karoly. "Transitions to Self-Employment at Older Ages: The Role of Wealth, Health, Health Insurance and Other Factors." Labour Economics 14 (2007): 269-95. 